\title{
A Comparison of Rusunawa A4 IPB Building Storey Shear using Seismic Code of SNI 1726-2002 and SNI 1726-2012
}

\author{
Isandre Fajarrachman $^{1, *}$, Erizal $^{2}$ and Meiske Widyarti ${ }^{3}$ \\ ${ }^{1}$ Graduate Civil and Environmental Engineering, Bogor Agricultural University \\ IPB Dramaga Campus PO. BOX 220 Bogor 16002 (West Java, Indonesia) \\ ${ }^{2}$ Department of Civil and Environmental Engineering, Bogor Agricultural University \\ IPB Dramaga Campus PO. BOX 220 Bogor 16002 (West Java, Indonesia) \\ ${ }^{3}$ Department of Civil and Environmental Engineering, Bogor Agricultural University \\ IPB Dramaga Campus PO. BOX 220 Bogor 16002 (West Java, Indonesia) \\ *Corressponding author's email: isandrefajar[AT]gmail.com
}

\begin{abstract}
Indonesia is a high-risk earthquake country. It passed by Pacific Ring of Fire and surrounded by Eurasian, Pacific, Philippines and Indo-Australian plates. Indonesia government has already made an earthquake anticipation with applied Indonesian National Standard (SNI)1726-2012 to prevent building collapse and structural failure. SNI 1726-2012 is an updated version of seismic standard code of SNI 1726-2002. The application of SNI 1726-2012 would make an existing building which was designed with SNI 1726-2002, generates a different result of storey shear. This situation made an uncertainty of building safety. The purpose of this study is to compare two storey shear between seismic code of SNI 1726-2002 and SNI 1726-2012 at the Rusunawa A4 IPB Building. This study used equivalent static method to obtain storey shear force based on the two of seismic standard code. The result of the comparison of storey shear between SNI 1726-2002 and SNI 1726-2012, it showed storey shear in SNI 1726-2012 at canopy storey-6, roof storey-5, storey-4, storey-3, storey-2 and story-1 are increased by $12.31 \%, 11.51 \%, 10.14 \%$, $8.59 \%, 6.48 \%$ and $3.01 \%$ compared to the storey shear in SNI 1726-2002.
\end{abstract}

Keywords - rusunawa IPB, earthquake, shear story

\section{INTRODUCTION}

Indonesia is a high-risk earthquake country. This is due to its location, it passed by pacific ring of fire and surrounded by eurasian plate, pacific plate, philippines plate, and indo-australian plate [1]. The tectonic plates at the meeting point are collide each other [2]. Most of earthquake casualities and damage costs are from structural failure and building collapse [3].

Indonesia's government has already made an earthquake anticipation with applied Indonesian National Standard (SNI) 1726-2012 to prevent building collapse and structural failure [4]. SNI 1726-2012 is an updated version of seismic standard code of SNI 1726-2002. SNI 1726-2012 is determined by 2475 years return period with $2 \%$ probability of exceedance in 50 years, whereas SNI 1726-2002 is determined by 500 years return period with $10 \%$ probability of exceedance in 50 years. 4-story building which designed using SNI 1726-2002 then get evaluated using SNI 1726-2012 with equivalent static method, it shows storey shear in SNI 1726-2012 are 5.04\% increase than SNI 1726-2002 [5]. 13Story Grand Egde Hotel Semarang was examined using SNI 1726-2012 with static equivalent method, it generates significant results of base shear are 2.5 times than SNI 1726-2002 [6]. Seismic design in SNI 1726-2012 is not constantly larger than seismic design in SNI 1726-2002, it depends on acceleration response spectrum at the seismic zone location [7].

The application of SNI 1726-2012 would make an existing building which was designed with SNI 1726-2002, generates a different results of storey shear. This situation made an uncertainty of building safety. The building needs to be re-calculated using newer seismic standard code of SNI 1726-2012 to estimate building perfomance from earthquake. This study used equivalent static method to obtain storey shear force based on the two of seismic standard code. The purpose of this study is to compare two storey shear between seismic code of SNI 1726-2012 and SNI 1726-2002 at the Rusunawa A4 IPB building. 


\section{METHODOLOGY}

This study was conducted in Rusunawa A4 IPB building, Babakan Village, Dramaga District, Bogor Regency, West Java. It started from February until March 2017. The data used in this study are shop drawing building, standard penetration test (SPT) data, seismic map of SNI 1726-2012 and seismic map of SNI 1726-2002. Location of study area is shown in Figure 1.

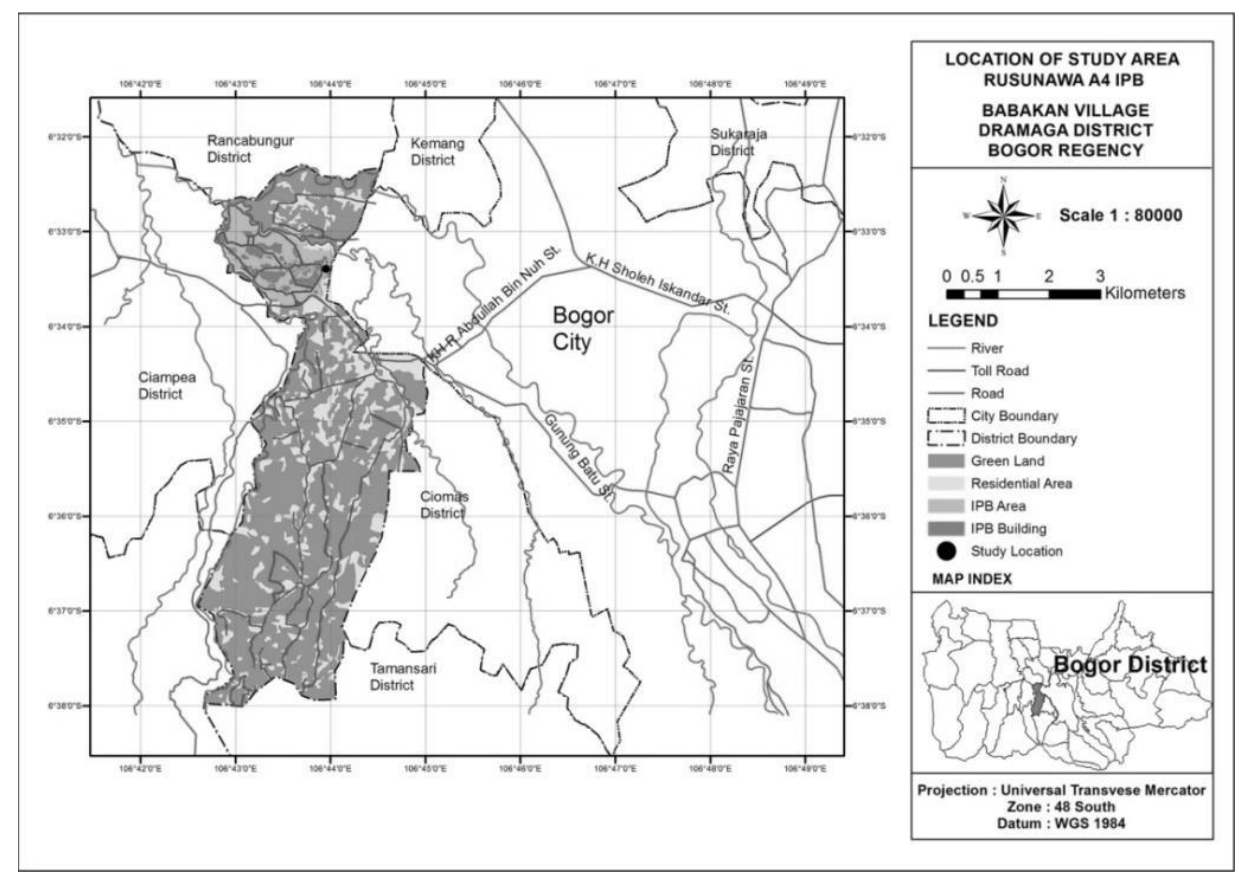

Figure 1. Location of study area

\subsection{Building Loads}

The building loads are based on the standard code of SNI 1726-2013 minimum load for building design and other structure [8]. The loads are used in this study are dead loads, live loads, and super imposed dead loads.

\subsection{Seismic Design SNI 1726-2002}

SNI 1726-2002 is determined by 500 years return period with $10 \%$ probability of exceedance in 50 years [10]. Earthquake-resistant building design is generally used response spectrum to obtain structural perfomance during seismic activity [11]. The peak ground acceleration (PGA) of SNI 1726-2002 is divided into six zones. The paramaters of response spectrum are determined by seismic acceleration coefficient (Ao) and seimic velocity coefficient (Am). Design response spectrum in SNI 1726-2002 are shown in Figure (3).

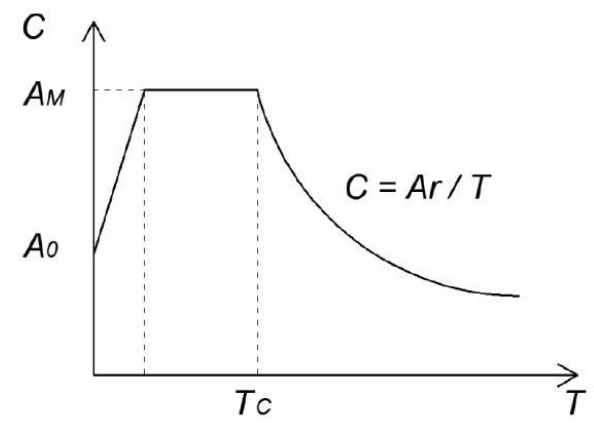

Figure 3. Design response spectrum in SNI 1726-2002

\subsubsection{Equivalent Static Analysis SNI 1726-2002}

The fundamental natural period $(\mathrm{T})$ of building with reinforced concrete moment-resisting frame is calculated using Eq. (12) and not to exceed the maximum limit of natural period (T.Max) as expressed in Eq.(13).

$$
T=0.00731 \times H
$$




$$
\text { T. } m a k s=\zeta \times n
$$

Where, $H$ is structure height, $\zeta$ is damping ratio and $n$ is total number of building storey.

The seismic response coefficient (C) is used to determine base shear is given by Eq. (14). The applied of equivalent static method on the building is generate base shear (V) can obtained by Eq. (15).

$$
\begin{aligned}
& C=\frac{A r}{T} \\
& V=\frac{C \times I \times W_{t}}{R}
\end{aligned}
$$

Where, Ar is seimic response factor coefficient and $W_{t}$ is is the effective seimic weight.

The distribution of the lateral force vertically $\left(\mathrm{F}_{\mathrm{X}}\right)$ along the height of the building can calculated using Eq. (15).

$$
\mathrm{F}_{\mathrm{X}}=\frac{W_{x} \times h_{x}}{\sum_{i=1}^{\mathrm{M}} W i \times h_{\mathrm{i}}} x V
$$

\subsection{Seimic Design SNI 1726-2012}

SNI 1726-2012 is determined by 2475 years return period with $2 \%$ probability of exceedance in 50 years [4]. Peak ground acceleration (PGA) of SNI 1726-2012 is divided into 18 zones.The parameters of response spectrum are determined by acceleration of short periods 0.2 second $\left(\mathrm{S}_{\mathrm{DS}}\right)$ by using Eq. (1) and acceleration of long periods 1 second $\left(\mathrm{S}_{\mathrm{D} 1}\right)$ by using Eq. (2). Short natural periods $\left(\mathrm{T}_{0}\right)$ can obtained using Eq. (3), long natural periods (Ts) can obtained using Eq. (4) and acceleration above 1 second (Sa) is given by Eq. (5). Design response spectrum in SNI 1726-2012 are shown in Figure (2).

$$
\begin{aligned}
S_{D S} & =\frac{2}{3} \times S_{M S} \\
S_{D I} & =\frac{2}{3} \times S_{M 1} \\
T_{0} & =0.2 \times \frac{S_{D_{1}}}{S_{D S}} \\
T S & =\frac{S_{D_{1}}}{S_{D S}} \\
S a & =S_{D S} \times\left(0.4+0.6 \times \frac{T}{T_{0}}\right)
\end{aligned}
$$

Where, $S_{M S}$ is spectral response accelerations for maximum considered earthquake adjusted for the site class at short periods and $S_{M I}$ is spectral response accelerations for maximum considered earthquake adjusted for the site class at 1 second periods.

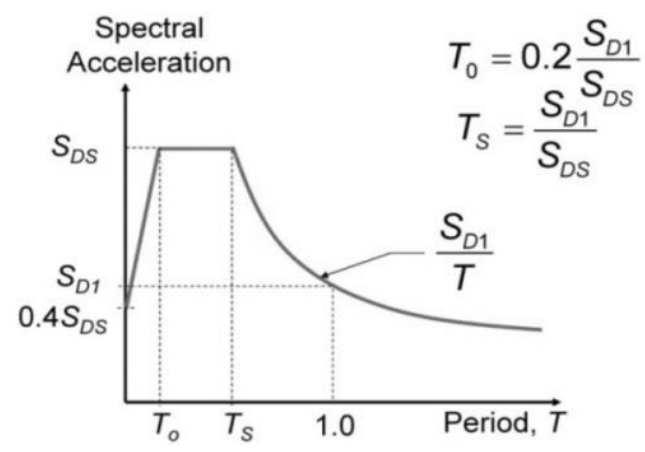

Figure 2. Design response spectrum in SNI 1726-2012

\subsubsection{Equivalent Static Analysis SNI 1726-2012}

The fundamental natural period (T) of building is calculated using Eq. (6) and not to exceed the maximum limit of natural period (T.Max) as expressed in Eq. (7).

$$
T \quad=C t \times H n^{x}
$$




$$
\text { T. Max }=C u \times T
$$

Where, $C t$ is building period coefficient depending on the type of seismic force resisting system, $H n$ is structure height $(\mathrm{mm}), x$ is building period formula exponent and $C u$ is upper limit coefficient.

The seismic response coefficient (Cs) is used to determine base shear is given by Eq. (8). The applied of equivalent static method on the building is generate base shear (V) can obtained using Eq. (9).

$$
\begin{aligned}
& C s=\frac{S_{D S}}{T\left(\frac{R}{I}\right)} \\
& V=C s \times W
\end{aligned}
$$

Where, $R$ is response reduction factor, $I$ is importance factor and $W$ is the effective seimic weight.

The increases force in storey shear could affected the structural building perfomance [9]. Seismic vertical distribution $(\mathrm{Fx})$ are applied to the building storey are given by Eq. (10). Vertical distribution factors $\left(\mathrm{C}_{\mathrm{VX}}\right)$ can obtained using Eq. (11).

$$
\begin{aligned}
F_{X} & =C_{V X} \times V \\
C_{V X} & =\frac{W_{x} \times h_{x}}{\sum_{i=1}^{n} W i \times h^{i k}}
\end{aligned}
$$

Where, $C v x$ is vertical distribution factors, $W x$ and $W i$ is portion of total effective seismic weight of the structure level $\mathrm{x}$ and $\mathrm{i}, h x$ and $h i$ is height from base to level $i$ and $x, k$ is exponent related to structure period.

\section{RESULT AND DISCUSSION}

\subsection{Building Description}

Rusunawa A4 IPB Building was built in 2006 by government program of KEMENPERA (Ministry of Public Housing) of rusunawa providers work unit. The rusunawa building is a multi-storey housing and designated for IPB student. General description of Rusunawa A4 IPB building are given in Table 1. The views of structural rusunawa A4 IPB building frames are shown in Figure 4.

Table 1. Rusunawa A4 IPB building description

\begin{tabular}{ll}
\hline \multicolumn{1}{c}{ Data Item } & \multicolumn{1}{c}{ Specifications } \\
\hline Building Structure & Special moment resisting frame system \\
Material & with shear wall in storey-1 \\
Building Types & Reinforced concrete \\
Number of storey & Mulistorey housing \\
Storey Height $(\mathrm{m})$ & 6 \\
& For storey $1,5: 3.4 \mathrm{~m}$ \\
& For storey $2,3,4: 3 \mathrm{~m}$ \\
Building height $(\mathrm{m})$ & For storey $6: 2.8 \mathrm{~m}$ \\
Building width $\left(\mathrm{m}^{2}\right)$ & $18.2 \mathrm{~m}$ \\
\hline
\end{tabular}
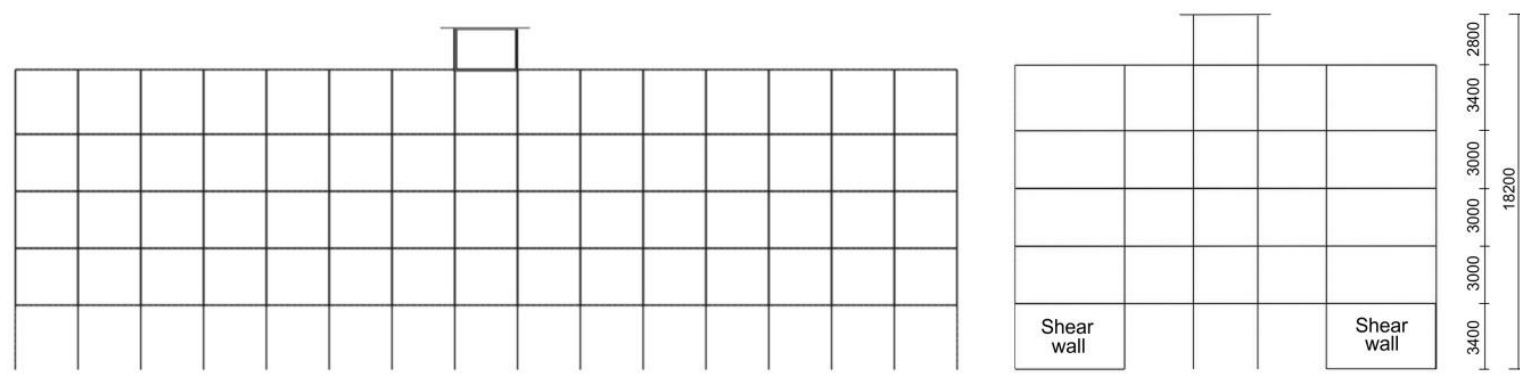

Figure 4(a). Front view of building frames

Figure 4(b). Side view of building frames 


\subsection{Building Loads}

The implementations of live loads are based on what types of rooms are used in the floor area of building. Dead loads of materials and construction weights are shown in Table 2. Live loads based on the types of room are shown in Table 3. Total storey loads are shown in Table 4.

Table 2. Dead loads of materials and construction weights

\begin{tabular}{lccc}
\hline \multicolumn{1}{c}{ Dead Load } & \multicolumn{3}{c}{ Weight } \\
\cline { 2 - 4 } & $(\mathrm{kN} / \mathrm{m})$ & $\left(\mathrm{kN} / \mathrm{m}^{2}\right)$ & $\left(\mathrm{kN} / \mathrm{m}^{3}\right)$ \\
\hline Reinforce concrete & & 15 & 23.53 \\
$\begin{array}{l}\text { Water tank } \\
\text { Half brick wall }\end{array}$ & 2.45 & 1.2 \\
$\begin{array}{l}\text { Super imposed dead loads (floor finish 2cm, ceiling }+ \\
\text { frames, ducting, ceramic tiles) }\end{array}$ & & \\
\hline
\end{tabular}

Table 3. Live loads based on the types of room

\begin{tabular}{lc}
\hline \multicolumn{1}{c}{ Live load } & $\begin{array}{c}\text { Weight } \\
\left(\mathrm{kN} / \mathrm{m}^{2}\right)\end{array}$ \\
\hline Private Rooms and corridors serving them & 1.92 \\
Public Rooms and corridors serving them & 4.79 \\
Roof & 0.96 \\
\hline
\end{tabular}

\begin{tabular}{|c|c|c|c|}
\hline Storey & $\begin{array}{c}\text { Live load } \\
(\mathrm{kN})\end{array}$ & $\begin{array}{c}\text { Dead load } \\
(\mathrm{kN})\end{array}$ & $\begin{array}{c}\text { Total load } \\
(\mathrm{kN})\end{array}$ \\
\hline Storey 6 ( canopy) & 3.85 & 99.57 & 119.48 \\
\hline Storey 5 (roof) & 232.98 & $5,599.17$ & $5,832.16$ \\
\hline Storey 4 & 501.92 & $8,183.71$ & $8,685.63$ \\
\hline Storey 3 & 477.69 & $8,183.71$ & $8,661.63$ \\
\hline Storey 2 & 501.92 & $8,183.71$ & $8,685.63$ \\
\hline Storey 1 & 517.75 & $8,625.48$ & $9,143.24$ \\
\hline
\end{tabular}

Live loads in effective seismic weight are used minimum $30 \%$ of actual live loads in building weight. Storey-1 had a largest floor area in the building, so it resulted total loads is 9,143.24 kN which the bigger loads Storey-6 only had a small canopy in the middle of building, so it resulted total loads only $119,48 \mathrm{kN}$.

\subsection{Response Spectrum}

Rusunawa A4 IPB building zone location is categorized into medium soil (SD). It affected a ground acceleration of response spectrum in SNI 1726-2012 at short periods 0.2-second (SDs) is $0.646 \mathrm{~g}$ and long periods 1 -seconds $\left(\mathrm{SD}_{1}\right)$ is $0.383 \mathrm{~g}$. In SNI 2002, Bogor regency is categorized into seismic zone IV and response spectrum are performed in seismic acceleration coefficient (Ao) is $0.28 \mathrm{~g}$ and seismic velocity acceleration (Am) is $0.70 \mathrm{~g}$. The design of two response spectrum are shown in Figure 5.

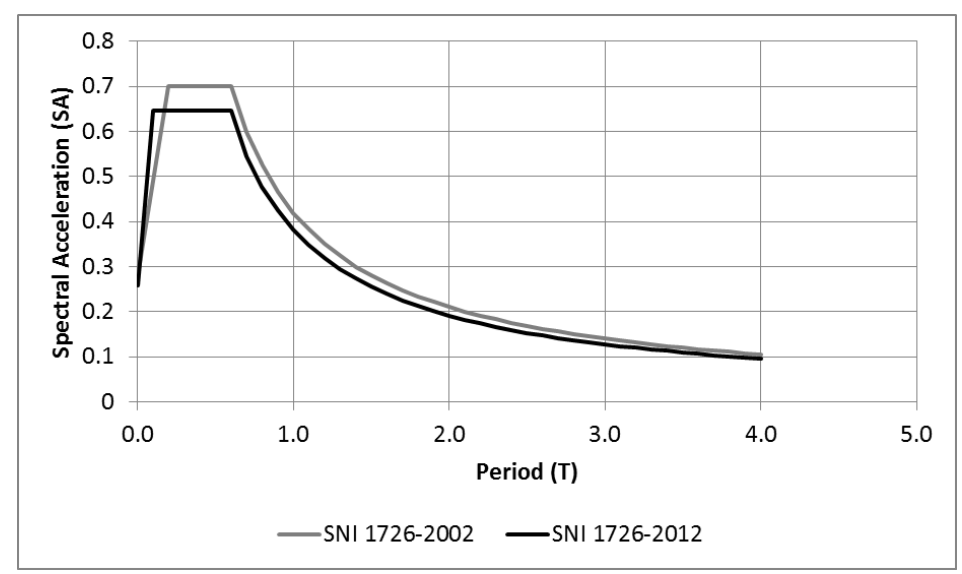

Figure 5. Design response spectrum in two code of SNI 1726-2002 and SNI 1726-2012 


\subsection{Storey Shear}

Response spectrum in SNI 1726-2002 is showed 7.07\% higher than SNI 1726-2012. The difference of response spectrum values are generates different lateral forces based on seismic design code. Base shear (V) of SNI 1726-2012 is $2215.32 \mathrm{kN}$ and base shear of SNI 1726-2002 is $2032.19 \mathrm{kN}$, it shows higher value in SNI 1726-2012 is increased by $9.01 \%$. The vertical loads are distributed as a lateral forces at the building storey. The results of storey shear in SNI 17262002 and SNI 1726-2012 are shown in Table 5.

Table 5. The comparison of storey shear of SNI 1726-2002 and SNI 1726-2012

\begin{tabular}{|c|c|c|c|c|c|}
\hline \multirow[b]{2}{*}{ Storey } & \multirow{2}{*}{$\begin{array}{l}\text { Height } \\
\text { (m) }\end{array}$} & \multicolumn{2}{|c|}{ SNI 1726-2002 } & \multicolumn{2}{|c|}{ SNI 1726-2012 } \\
\hline & & $\begin{array}{c}100 \% \mathrm{Fx} \\
(\mathrm{kN})\end{array}$ & $\begin{array}{c}30 \% \mathrm{Fx} \\
(\mathrm{kN})\end{array}$ & $\begin{array}{c}100 \% \mathrm{Fx} \\
(\mathrm{kN})\end{array}$ & $\begin{array}{c}30 \% \mathrm{Fx} \\
(\mathrm{kN})\end{array}$ \\
\hline Storey 6 ( canopy) & 18.2 & 11.94 & 3.58 & 13.41 & 4.02 \\
\hline Storey 5 (roof) & 15.8 & 505.95 & 151.79 & 564.17 & 169.25 \\
\hline Storey 4 & 12.4 & 591.35 & 177.41 & 651.30 & 195.39 \\
\hline Storey 3 & 9.4 & 447.04 & 134.11 & 485.45 & 145.64 \\
\hline Storey 2 & 6.4 & 305.21 & 91.56 & 325 & 97.50 \\
\hline Storey 1 & 3.4 & 170.69 & 51.21 & 175.99 & 52.80 \\
\hline
\end{tabular}

The comparison of two seismic standard code between SNI 1726-2002 and SNI 1726-2012. It shows storey shear at canopy storey-6, roof storey-5, storey-4, storey-3, storey-2 and storey-1 in SNI 1726-2012 are increased by $12.31 \%$, $11.51 \%, 10.14 \%, 8.59 \%, 6.48 \%$ and $3.01 \%$ compared to the storey shear in SNI 1726-2002. A comparison of the two seismic standard code are presented in graph curves at Figure 6.

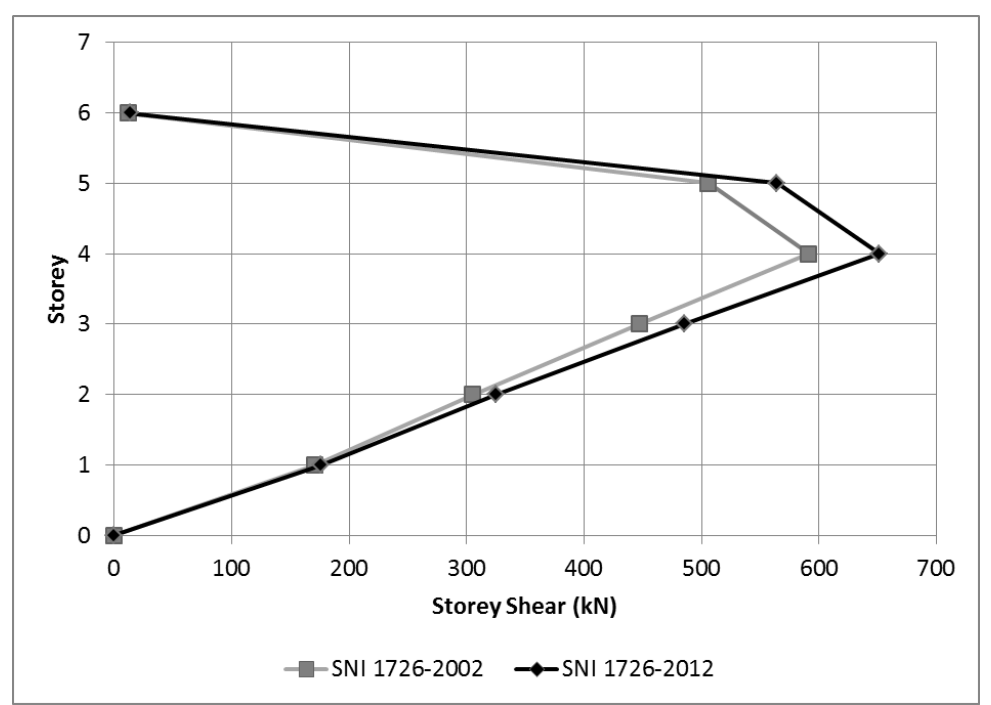

Figure 6. A comparison of storey shear between SNI 1726-2002 and SNI 1726-2012

\section{CONCLUSION}

The comparison of storey shear between SNI 1726-2002 and SNI 1726-2012. It shows storey shear in SNI 1726-2012 at canopy storey-6, roof storey-5, storey-4, storey-3, storey-2 and storey-1 are increased by $12.31 \%, 11.51 \%, 10.14 \%$, $8.59 \%, 6.48 \%$ and $3.01 \%$ compared to the storey shear in SNI 1726-2002. The increases of storey shear in SNI 17262012 made an uncertain building safety. Rusunawa A4 IPB building needs to be analyzed more detail in interstory drift, bending moment, and shear force using newer seismic standard code of SNI 1726-2012 to ensure the building safety perfomance.

\section{REFERENCES}

[1] Hamilton W. Tectonics of the Indonesian Region, US Government Printing Office, US, 1979.

[2] Bock Y, Prawirodirdjo L, Genrich JF, Stevens CW, McCaffrey R, Subarya C, Puntodewo SSO, Calais E. Crustal motion in indonesia from global positioning system measurements. Journal of Geophysical Research. vol. 108, no.B8 pp.1-17, 2003. 
[3] Irsyam M, Sengara W, Aldiamar F, Widiyantoro S, Triyoso W, Natawidjaja DH, kertapati E, Meilano I, dan Suhardjono. Ringkasan Hasil Studi Tim Revisi Peta Gempa Indonesia 2010, Kementrian Pekerjaan Umum, ID, 2010.

[4] Badan Standardisasi Nasional (BSN). SNI 1726-2012 Standar Perencanaan Ketahanan Gempa Untuk Struktur Bangunan Gedung, BSN, ID, 2012.

[5] Purnijanto B, Wiwoho M, Crista HN. Perbandingan analisis struktur gedung fakultas psikologi USM (Empat Lantai Gedung T) menggunakan SNI gempa 03-1726-2002 dengan SNI gempa 03-1726-2012. Journal Teknika. vol. 1, no.1 pp.12-22, 2015.

[6] Setiawan AA. Studi perbandingan gaya geser dasar seismik berdasarkan SNI-03-1726-2002 dan SNI 031726-2012 studi kasus struktur gedung grand edge semarang. Journal Teknik Sipil \& Perencanaan. vol. 16, no.2 pp.95-104, 2014.

[7] Cornelis R, Bunganaen W, Tay UHB. Analisis perbandingan gaya geser tingkat, gaya geser dasar, perpindahan tingkat dan simpangan antar tingkat akibat beban gempa berdasarkan peraturan gempa SNI 1726-2002 dan SNI 1726-2012. Journal Teknik Sipil. vol. 3, no.2 pp.205-216, 2014.

[8] Badan Standardisasi Nasional (BSN). SNI 1727-2013 Standar Perencanaan Ketahanan Gempa Untuk Struktur Bangunan Gedung, BSN, ID, 2013.

[9] Faizah R, Widodo. Analisis gaya gempa rencana pada struktur bertingkat banyak dengan metode dinamik respon spektra, Peran Teknik Sipil dan Lingkungan Dalam Pembangunan Yang Berkelanjutan, At Surakarta, 24-26 Oktober 2013, vol.1, pp. S299-S306, 2013.

[10] Badan Standardisasi Nasional (BSN). SNI 1726-2002 Standar Perencanaan Ketahanan Gempa Untuk Struktur Bangunan Gedung, BSN, ID, 2002.

[11] Rendra R, Kurniawandy A, Djauhari Z. Kinerja struktur akibat beban gempa dengan metode respon spektrum dan time history, inovasi rekayasa sipil dalam menunjang pembangunan infrastruktur dan mitigasi bencana di lahan gambut 1st annual civil engineering seminar, At Pekanbaru, 21 November 2015, vol.1, no.1, pp. 153-161, 2015. 